\title{
The left hand of the Enlightenment: truth, error, and integrity in Bayle and Kant*
}

\author{
Mara van der Lugt \\ School of History, University of St Andrews, St Andrews, UK \\ $\underline{\text { mvdl@st-andrews.ac.uk }}$
}

\begin{abstract}
Taking its cue from Hannah Arendt's comment that 'truth gets lost in the Enlightenment' and Lessing's parable of God's 'left hand', this paper traces a historical shift in moral and religious thought: roughly from truth to sincerity. From traditional conceptions of conscience as conditional on the objective truth of its content, the paper moves on, via the Reformation and seventeenth-century Augustinian turn, to early modern debates on toleration and the 'erring conscience'. It is argued that Pierre Bayle's Commentaire Philosophique of 1686 can be read as a crucial catalogue for understanding the substitution of truth with sincerity (and error): so that not truth but truthfulness is considered to be essential for moral and religious justification. Moving from Bayle to Immanuel Kant, the paper then shows how many of the same questions rise in Kant's late essay on theodicy, which is also an essay on sincerity or integrity, via the Book of Job. Through these two thinkers, various themes are connected: from conscience and sincerity to the problem of the conscientious persecutor. Finally, these themes of truth, error and integrity are linked to the modern debate on authenticity, and a framework is proposed for conceptualising these various shifts.
\end{abstract}

The very young Hannah Arendt once wrote: 'Truth gets lost in the Enlightenment - indeed, no one wants it anymore'. ${ }^{1}$ She goes on to cite a rather notorious passage by the eighteenth-century theologian and playwright Gotthold Ephraim Lessing:

Not the truth which someone possesses or believes he possesses, but the honest effort he has made to get at the truth, constitutes a human being s worth. [...]

If God held fast in his right hand the whole of truth and in his left hand only the single and untiring striving after truth [den einzigen immer regen Trięb nach Wahrheit], albeit with the proviso that I should constantly and eternally err, and said to me: 'Choose!', I would humbly fall upon his left hand and say: 'Father, give! For pure truth is for you alone! ${ }^{\prime}$

\footnotetext{
*This article is based on the Haydn Mason Lecture, delivered in Oxford on 4 January 2018, for which I thank the British Society for Eighteenth-Century Studies. I also thank Anthony La Vopa and Ritchie Robertson, for their inspiring comments and conversations. 'Hannah Arendt, 'The Enlightenment and the Jewish Question' (first published 1932), in The Jewish Writings, ed. Jerome Kohn and Ron Feldman (New York, 2007), 4.

2(My italics.) Gotthold Ephraim Lessing, 'A Rejoinder' (1778), in Philosophical and Theological Writings, trans. H.B. Nisbet (Cambridge: Cambridge University Press, 2005), 95-109, at 98. I have adapted Nisbet's translation via Wittgenstein's friend Drury, who translates 'den einzigen immer regen Trieb nach Wahrheit' with 'single and untiring striving after truth' rather than the less passionate 'ever-active quest for truth' (Nisbet's edition) See M.O'C. Drury, 'Conversations with Wittgenstein', in Recollections of Wittgenstein, ed. R. Rhees (Oxford: Oxford University Press, 1984), 97-171, at 134. In the original: 'Nicht die Wahrheit, in deren Besitz irgend ein Mensch ist, oder zu sein vermeint, sondern die aufrichtige Mühe, die er angewandt hat, hinter die Wahrheit zu kommen, macht den Wert des Menschen. [...] Wenn Gott in seiner Rechten alle Wahrheit, und in seiner Linken den einzigen immer regen Trieb nach Wahrheit, obschon mit dem Zusatze, mich immer und ewig zu irren, verschlossen hielte, und spräche zu mir: wähle! Ich fiele
} 
Some passages in the history of philosophy, more than others, have the capacity to reverberate and of course they do so differently at different times. This is one such passage, cited again and again in centuries to come, all the way up to more quintessentially 'modern' figures like Kierkegaard and Wittgenstein (and, of course, Arendt herself). ${ }^{3}$ It seems that Lessing has captured something profound with this left hand of his, though it is hard to put the finger on what exactly it is that he has captured. Something to do with truth, as opposed to something else - but what is this truth, and what is this something else to which it is opposed? If truth is truly lost in the Enlightenment, what does this truth look like, and what is it that is discovered or promoted in its stead?

In what follows I will be asking some questions about what happens to truth (by which I mean primarily moral and religious truth) in the Enlightenment, or rather, the very long eighteenth century, including significant portions of the seventeenth. I will be looking, not merely or even primarily at truth, but at various clusters of terms and concepts related to truth and its opposites such as, on the one hand, sincerity, integrity, authenticity, truthfulness, and conscience; and, on the other, lies, deception, falsehood, hypocrisy, and error. I will be engaging in this unconventional quest for truth by an even more unconventional method: rather than trying to reconstruct a single historical narrative, I will be looking at these questions as at the patterns in a tapestry, picking up various threads and strains here and there, so as together to weave a picture or a story. In fact I will be going at this from opposite ends, as it were, focusing especially on two thinkers standing on either side of the development I am trying to trace (roughly: from truth to integrity), two thinkers divided by background, language, culture, and just about a hundred years. Their names are Pierre Bayle and Immanuel Kant.

\section{Error}

Not only passages have the power to reverberate - sometimes very titles can do the same. I'm thinking especially of Paul Hazard's winged phrase, la crise de la conscience européenne, which is usually translated as a crisis of the European mind (or Geist) rather than the European conscience (or Gewis-sen). ${ }^{4}$ This has to do with the ambiguity of the French term conscience, which at some point in the early modern period begins to shift from its traditional moral meaning (conscience proper) to a more neutral psychological concept (which in English would become consciousness): a development that takes place especially in and through Cartesian philosophy. ${ }^{5}$ But, however, we translate Hazard's title, its message is valid: for it can equally be said that the seventeenth century saw a crisis of the European conscience, in this moral sense of the term (the German Gewissen).

Like so many other crises, spiritual and otherwise, this too was inaugurated by the Reformation, which disrupted a traditional dichotomy between truth on the one hand, and, on the other, the conglomerate of its opposites: error, deception, falsehood, lies. These opposites of truth were, at least in the religious domain, not so clearly or eagerly distinguished. ${ }^{6}$ What mattered was to belong to the

inm mit Demut in seine Linke, und sagte: Vater gieb! die reine Wahrheit ist ja doch nur für dich allein!' Lessing, 'Eine Duplik' (1778), Theologische Streitschriften, in Werke Vol. 10 (Leipzig: Göschen, 1867), 19.

${ }^{3}$ See Søren Kierkegaard, Concluding Unscientific Postscript, trans. David F. Swenson and Walter Lowrie (Princeton, NJ: Princeton University Press, 1974), 97ff; Wittgenstein, as remembered by Drury, 'Conversations', 134. Note that, while Arendt only cites the first part of the passage, Kierkegaard and Wittgenstein only cite the second part.

4Paul Hazard, La crise de la conscience européenne, 1680-1715 (Paris: Boivin, 1935).

${ }^{5}$ See e.g. Boris Hennig, 'Cartesian Conscientia', British Journal for the History of Philosophy 15, (2007): 455-84.

The ambiguity still gives rise to linguistic confusions: thus Gianluca Mori ('Pierre Bayle, the Rights of the Conscience, the "Remedy" of Toleration', Ratio Juris 10, no. 1 (March 1997): 45-60, at 52-3), in signalling this moral-to-psychological shift, seems to think it is internal to conscience proper, when the shift is rather from conscience to consciousness (both designated as conscience in French and conscientia in Latin). Thus, when Malebranche equates conscience (in French) with inner sentiment, he is not speaking of conscience proper, as Mori suggests, but of consciousness.

${ }^{6}$ With regard to morality, there is sometimes a clearer contrast: thus Augustine in De mendacio (ca. $395 \mathrm{AD}$ ) strongly emphasises the aspect of intention in lies, as distinguished from error; though he leaves open the question whether only falsehoods uttered with the will to deceive are lies (De mendacio 3,5). With regard to religious belief, however, the matter is not so clear-cut: generally it is the (persistent) opposition to the truth that indicts the heretic. For Augustine, ignorance and error are themselves the penalty of sin (see On Nature and Grace, ch. 81); sin is an act against God's law even if it was not intended as such a violation (John Kilcullen, 
realm of Truth, and avoid all association with sin and falsehood; sin itself being, on the Augustinian view, 'the deliberate dissociation from truth' 7 Access to the truth, furthermore, was safeguarded by the authority of the Catholic Church, for which pagans and heretics posed practical problems to a much greater extent than they did theoretical or spiritual ones. Conscience of old was a faculty crucially associated with a higher power, an external law, both natural and divine, and conscience could be accessed and tested through the institute of confession, which ensured the vital connection between conscience and truth. ${ }^{8}$

The Reformation disturbed both elements of this connection, as well as the connection itself. For one thing, the main opponent of truth now lay not outside but inside Christianity, and it was unclear how those on the other side should be evaluated. Considering the large number of 'mistaken' souls, it was obvious that religious error was possible - but was it innocent? When the truth was so widely available, could a Christian heretic be forgiven for not seeing it? Was this a case of innocent error, of merely philosophic sin, or was it a case of wilful blindness, of self-deception, of sinful forgetfulness of God? ${ }^{9}$

Such questions were rendered even more acute in the seventeenth century, with its strong Augustinian turn - a turn that was marked by an emphatic concern for human culpability, in both Catholic and Protestant thought. ${ }^{10}$ It also involved new theoretical underpinnings justifying the forcing of conscience, explicitly invoking the age-old Augustinian principle of compelle intrare: compel them to come in - which, in the words of Mark Goldie, was to become 'the canonical citation in the history of persecution'. ${ }^{11}$

The overall result of these developments was a huge burden on conscience to be justified, to be right or true, while ignorance and error were increasingly associated with self-deception, wilful blindness, with lying - and thus with moral culpability. ${ }^{12}$ This burden of conscience, this duty of truth took place both on individual and societal level, and led to a culture of mutual intolerance and suspicion. ${ }^{13}$ As Harry Bracken has argued, the radical mental privacy that the Reformation installed in the individual conscience led to new attempts to regain access to this utterly private mind; even to 'externalise the mind'. This explains the new importance in the seventeenth and eighteenth centuries of oaths and oath-taking, which were part of this 'recovery operation'. ${ }^{14}$ Hence, with its extreme emphasis on the individual conscience, the Reformation had invited new sets of problems: problems of truth, problems of guilt, and problems of access. These, furthermore, were problems that applied to both sides of the confessional divide.

The words of the day were conscience and error. And so it is perhaps not surprising that the two were combined into an incredibly important concept which was not itself new, but which was imbued with a new sense of urgency and moved to the very centre of the theological, philosophical, and political debate. This is the concept of the erring conscience, a conscience that is earnestly deluded: what rights should such a conscience have?

'Arnauld against Philosophic Sin', in Sincerity and Truth: Essays on Arnauld, Bayle and Toleration (Oxford: Oxford University Press, 1988), 37-8); obstinacy distinguishes heresy from error (John Marshall, John Locke, Toleration and Early Enlightenment Culture (Cambridge: Cambridge University Press, 2006), 202).

${ }^{7}$ Hennig, 'Cartesian Conscientia', 472. On Augustine's view of Truth as a 'separately existing Wisdom above the soul' see Stephen Menn, Descartes and Augustine (Cambridge: Cambridge University Press, 1998), 154-55.

${ }^{8}$ On conscience and confession, see e.g. Hennig, 'Cartesian Conscientia', esp. 475-81; Jean Delumeau, 'Prescription and Reality', in Conscience and Casuistry in Early Modern Europe, ed. Edmund Leites (Cambridge: Cambridge University Press, 1988), 134-58.

${ }^{9}$ On these questions, and especially the Jesuit-Jansenist debate on philosophic sin, Kilcullen, 'Arnauld', 7-53. On the early modern debate on self-deception, see Aaron Garrett, 'Self-Knowledge and Self-Deception in Modern Moral Philosophy', in Self-Knowledge: $A$ History, ed. Ursula Renz (Oxford: Oxford University Press, 2017), 164-182.

${ }^{10}$ For a clear and concise introduction on seventeenth-century Augustinianism, see Michael Moriarty, Early Modern French Thought: The Age of Suspicion (Oxford: Oxford University Press, 2003), esp. 18-49; see also Delumeau, 'Prescription'.

${ }^{11}$ Mark Goldie, 'The Theory of Religious Intolerance in Restoration England', in From Persecution to Toleration: The Glorious Revolution and Religion in England, ed. Ole Peter Grell, Jonathan I. Israel, and Nicholas Tyacke (Oxford: Clarendon, 1991), 331-68, at 338.

${ }^{12}$ See again Kilcullen, 'Arnauld'; on the rising theme of wilful blindness and self-deception, especially in the Jansenists and French Moralists, see Garrett, 'Self-Knowledge'; on self-deception in Pascal see William Wood, Blaise Pascal on Duplicity, Sin, and the Fall: The Secret Instinct (Oxford: Oxford University Press, 2013), esp. 121-45.

${ }^{13} \mathrm{Cf}$. Delumeau's account of a 'surplus of conscience' ('Prescription', 150); Harry Bracken, 'Minds and Oaths', in Mind and Language:

Essays on Descartes and Chomsky (Dordrecht: FORIS, 1983), 67-82.

${ }^{14}$ Bracken, 'Minds and Oaths', esp. 67-71. 
The stakes in this debate could not be higher: they included toleration and freedom of conscience, but also, the duty to defend the truth. The early theorists of erring conscience were generally eager to claim the rights of error, the right to be mistaken, for their own party, but less certain about allotting such rights to their opponents. After all, it is one thing to make the case for toleration while being the party oppressed; it is quite another to promise never to defend the truth by the forcing of conscience when the tables are turned. ${ }^{15}$ This shows that there was a background asymmetry in place: when speaking of error, often what was meant was not real error, but truth mistaken for error by one's opponents, who were erring themselves. Double error, therefore: an ethic of the double negative. What is taken for error by the erring is in fact still truth. And so the foundations of toleration were not yet shifting as deeply as, on the surface, they seemed to be.

The watershed is this: the apologists of tolerance and intolerance shared a profound concern for objective truth, until they did not. At some point the tolerationists traded in truth for error; or, more appropriately, they traded in truth for truthfulness. While most of these developments are subtle, gradual, and fluid, this particular one is not: we have the very manual and catalogue of this trade in the works of the French philosopher Pierre Bayle, where the debate reaches an abrupt climax.

\subsection{Bayle and the erring conscience}

Very briefly, Bayle's famous Commentaire Philosophique of 1686, which has been described as 'certainly one of the great events in French intellectual history', does two things. ${ }^{16}$ First, arguing from the principles of natural reason, but also from the ethics of the Gospel, Bayle delivers a confident pointby-point refutation of the Augustinian principle of compelle intrare. This in itself was an intervention as drastic as it was influential, to the point that the Victorian thinker William Lecky wrote that Bayle '[broke] the spell which St. Augustine had so long cast over theology' ${ }^{17} \mathrm{He}$ did so in typically idiosyncratic fashion, posing as a Socinianising Englishman ('Jean Fox de Bruggs') and indeed skimming quite deliberately along the dangerous margins of Socinianism, arguing that theology is the handmaiden of philosophy, not vice versa, and that faith should be subject to reason in matters of morality. But in this very rationalist impulse Bayle was still perfectly poised in his historical climate: the fundamental principles that violence and force are condemned both by reason and by the spirit of the Gospel were being taken up by other toleration thinkers of the time, creating the experience of a community of tolerationists, les Tolérants. ${ }^{18}$ These, in their eagerness to count Bayle among their ranks, were willing to read the Baylean exaggerations in a more forgiving light than his enemies did, and his arguments, suitably toned down, were widely repeated; arguably it was this very toning-down that allowed them to take their spell-breaking form.

And so Bayle might well have left it there. Instead, in the second part of the Commentaire, as well as in various other writings preceding and following it, he introduces a second foundation for toleration: that error has the same rights as truth. ${ }^{19}$ Since we have no infallible way of discerning religious truth from error, all of our duty resides in following our conscience, and adhering to that which we feel to be true:

\footnotetext{
${ }^{15}$ See e.g. Rex, Essays, 189-93, 244-5.

${ }^{16}$ Rex, Essays, 153. On the Commentaire, see e.g. John Kilcullen, 'Bayle on the Rights of Conscience', in Sincerity and Truth: Essays on Arnauld, Bayle and Toleration (Oxford, 1988), 54-105; Mori, 'Pierre Bayle'; Rex, Essays, 153-93. The literature on Bayle is vast, but for the classics, see Élisabeth Labrousse, Pierre Bayle, Tome II: Hétérodoxie et rigorisme (The Hague: Martinus Nijhoff, 1964) and Gianluca Mori, Bayle philosophe (Paris: Champion, 1999).

${ }^{17 W . E . H . ~ L e c k y, ~ H i s t o r y ~ o f ~ t h e ~ R i s e ~ a n d ~ I n f l u e n c e ~ o f ~ t h e ~ S p i r i t ~ o f ~ R a t i o n a l i s m ~ i n ~ E u r o p e ~(L o n d o n, ~ 1865), ~ i i . ~ 65, ~ q u o t e d ~ i n ~ G o l d i e, ~ ' T h e o r y ', ~}$ 339.

${ }^{18}$ See Marshall, John Locke, esp. ch. 16; Mara van der Lugt, Bayle, Jurieu and the Dictionnaire Historique et Critique (Oxford: Oxford University Press, 2016), 150-56.

${ }^{19}$ See Commentaire Philosophique sur ces paroles de Jésus-Christ, Contrains-les d'entrer (1686-88) [CP], but also Nouvelles Lettres de l'Auteur de la Critique Générale de l'Histoire du Calvinisme de Mr. Maimbourg (1685) [NLCG]; henceforth both cited (in modernised French) from Bayle's CEuvres Diverses (4 vols., The Hague [Trévoux] 1737) [OD].
} 
... whatever a Conscience well directed allows us to do for the Advancement of Truth, an erroneous Conscience will warrant for advancing a suppos'd Truth. ${ }^{20}$

Hence, what matters is not whether something is objectively true, since we have no infallible way to access this truth, but whether it is subjectively taken to be true. What matters is that one follows one's conscience, taken as one's most inner sentiment, whatever that entails:

... when error becomes a truth in our eyes, it receives all the rights of truth with respect to us; and when truth presents itself to us in the form of a lie, it loses all its authority on us. ${ }^{21}$

There are, then, some tensions between Bayle's two foundations of toleration - the rationalistic principles of the first part (based on truth), and the sceptical principles of the second part (based on error). ${ }^{22}$ Why Bayle built up his argument in this way is a matter of debate, but one factor seems to be that Bayle wanted to ensure complete reciprocity in the argument; to supply the theoretical building blocks for truly radical toleration. That is, to prevent the so-called half-tolerationists ('DemiTolérants') from blocking the way to toleration from those who do not share in their 'truth':

These Gentlemen, either to enjoy the Comforts of Toleration without losing the Pleasure of Persecution, or from some other honester Reason, wou'd fain split the Difference, and say, there are some Sects which may be tolerated, but that there are others which deserve to be extirpated, if not by Fire and Sword, at least by Banishment and Confiscation. ${ }^{23}$

Toleration, for Bayle, cannot be a half-and-half thing. Whether in terms of means (from the extreme of violence to the supposedly milder option of banishment or financial repercussions) or ends (from total to selective persecution), there is no compromise here: it is all or nothing. If the forcing of conscience is recognised as a moral obligation, then it follows that we are all equally obliged to persecute those we consider heretics, and to do so to the best of our abilities:

The middle way in many cases is certainly the best, and the Extremes faulty; this happens very often: but here we can fix on no just Medium; either we must allow all or none; there can be no solid Reason for tolerating any one Sect, which does not equally hold for every other. ${ }^{24}$

If anyone has a right to force conscience or to persecute, then everyone does; to have the truth on one's side is utterly irrelevant, since everyone believes to own this truth. Hence, if a heretic persecuting the orthodox is a sin, then so too is the orthodox persecuting a heretic. And in fact, as Mark Goldie has shown, the very notion of persecution, which originally was only applied to the martyrdom of the true faith, in this era gets reinvented to stand for religious violence of any kind. ${ }^{25}$

To ensure this reciprocity, Bayle's philosophy of toleration sets up a perfect symmetry between error and truth, to the point that the two become mutually exchangeable:

${ }^{20} 0^{\prime} .$. que tout ce que la conscience bien éclairée nous permet de faire pour l'avancement de la vérité, la conscience erronée nous le permet, pour ce que nous croyons la vérité' (OD.II.422). Unless otherwise stated, all English translations of the CP from: Pierre Bayle, A Philosophical Commentary on These Words of the Gospel, Luke 14.23, 'Compel Them to Come In, That My House May Be Full', ed. John Kilcullen and Chandran Kukathas (Indianapolis: Liberty Fund, 2005), http://oll.libertyfund.org/titles/163 (accessed January 23, 2018).

${ }^{21} \mathrm{NLCG}$, OD.II.219. (My translation). Note that Bayle and critics sometimes use error and lie interchangeably, as in this passage: 'lors que l'erreur devient une vérité à notre égard, elle entre en possession de tous les droits de la vérité à notre égard ; \& lorsque la vérité se montre à nous sous la forme du mensonge, elle perd tout ce qu'elle avait d'autorité sur nous.'

${ }^{22}$ See e.g. Rex, who suggests that Bayle is drawing upon 'two traditional Protestant perspectives', associated with the intellect (part I) and the will (part II); see Essays, 173, 181; also Mori, 'Pierre Bayle', 51-5.

${ }^{23}$ CP.II.7. 'Ces Messieurs, soit pour jouir des commodités de la tolérance, sans perdre le plaisir de persécuter, soit pour d'autres raisons plus honnêtes, coupent le différend par la moitié, \& disent qu'il y a des Sectes qu'il faut tolérer, \& d'autres qu'il faut extir-per, sinon par le fer \& le feu, à tout le moins par l'exil \& par les confiscations' (OD.II.421).

${ }^{24}$ CP.II.7. 'Il y a des occasions où les sentiments moyens sont les meilleurs, et les deux extrémités vicieuses ; cela est même fort fréquent, mais en cette rencontre on ne saurait trouver de juste milieu; il faut tout ou rien. On ne peut avoir de bonnes raisons pour tolérer une Secte, si elles ne sont pas bonnes pour en tolérer une autre ... ' (OD.II.419).

${ }^{25}$ Goldie, 'Theory', 358-61. Bayle does a similar thing with the concept of blasphemy, inverting it so that it is centred, not on truth, but on intention: an utterance is only blasphemous when it goes against the specific beliefs of whoever utters it; it is not blasphemous if it goes against a doctrine that that person disowns, even if that doctrine is objectively true or divine. See CP.II.7. 
... an erroneous Conscience challenges all the same Prerogatives, Favours, and Assistances for an Error, as an Orthodox Conscience can challenge for the Truth. ${ }^{26}$

Bayle was not the first to defend the rights of the erring conscience, but he did take it to its furthest consequence. ${ }^{27}$ He turned the relationship between truth and intention on its head, so that subjective truth (truthfulness or sincerity) is all that matters, while objective truth becomes almost irrelevant, or obsolete. At the same time, intention becomes, not only crucial, but absolute. The new focal point of toleration is the individual conscience, regardless of its objective content; what matters is not truth but truthfulness, or sincerity, or wholeheartedness. The moral principle for belief as well as action is that one follow one's conscience; that one is in good faith, whether or not that faith be objectively true. ${ }^{28}$ This means that a heretic in good faith - someone who believes an objective falsehood with wholehearted persuasion - is more pleasing to God, and more morally justified, than a halfhearted proponent of the true faith - someone who espouses an objective truth but not out of personal conviction. ${ }^{29}$

This principle drives deeply into Bayle's ethics. He speaks not only of the rights of the erring conscience, but also of its duties: the duty to follow one's conscience, erring or no, even up to the point of immorality. This leads Bayle into some difficulties, the most obvious one being that of the 'conscientious persecutor'. For, as Bayle anticipates his critics' objections, doesn't his theory entail that 'every one who thinks himself oblig'd in Conscience to persecute, shall be oblig'd by [this] Doctrine to persecute, and sins if he does not'? Doesn't it mean that Bayle's entire theory of toleration ends up supplying a moral justification of persecution? ${ }^{30}$

Bayle generally bites the bullet with regard to such problems: yes, he admits, according to his theory those who truly and wholeheartedly believe it is their duty to persecute are obliged to 'follow the Motions of their false Conscience'; indeed, if they fail to do so, 'they are guilty of a Disobedience to God, because they persist in not obeying what they believe to be his Will'. ${ }^{31}$ However, even if such erring persecutors are morally justified, this does not mean we should not try to correct their errors - and correcting the erroneous belief that Christ commands persecution is precisely the design of (especially the first part of) the Commentaire. ${ }^{32}$ Similarly, a conscientious murderer may indeed be fully justified, even laudable, in terms of his intentions, but this does not mean the magistrate should not to try to stop him or punish him. Speaking strictly in moral terms, a conscientious murderer who refrains from killing though his conscience dictates it is more morally culpable than someone who kills another against his conscience - but the magistrate should punish the latter rather than the former. After all, only God has perfect access to our true intentions; it is not in the power of the magistrate to search our hearts. So too, regardless of the persecutor's intentions, his putting them into practice must nevertheless be prevented, since it's harmful to society at large. ${ }^{33}$

But something is off: a morally perfect persecutor in a treatise against persecution? Bayle feels the tension but, perhaps to his credit, does not quite resolve it. He does admit some embarrassment on

\footnotetext{
${ }^{26}$ CP.II.8. 'que la conscience erronee doit procurer à l'erreur les mêmes prerogatives, secours \& caresses que la conscience ortho-doxe procure à la verite.' (OD.II.425).

${ }^{27}$ Note that even Bayle's supporters thought his doctrine of the erring conscience excessive; see e.g. Bracken, 'Toleration Theories: Bayle, Jurieu, Locke', in Mind and Language, 83-96, at 87, for Basnage's critique; and Van der Lugt, Bayle, 154.

${ }^{28}$ Bayle often uses bonne foi when speaking of sincerity.

${ }^{29}$ The same holds for blasphemy (see above, n. 25). On sincerity vs truth in Bayle, see Kilcullen, 'Bayle on the Rights of Conscience', 54105.

${ }^{30}$ CP.II.9. ' ... tout homme qui se croira oblige en conscience de persecuter, sera oblige, selon moi, de persecuter, \& ferait mal de ne persecuter pas' (OD.2.430). See also Pierre Jurieu, Des Droits des deux Souverains (1687), 68:' ... les persecuteurs entêtes de l'opi-nion qu'on doit brûler les heretiques, doivent à cette erreur habillee chez eux en verite les hommages de l'obeissance'.

${ }^{31} \mathrm{CP}$.II.9.'Je ne nie pas que ceux qui sont actuellement persuades qu'il faut, pour obeir à Dieu, abolir les Sectes, ne soient obliges de suivre les mouvements de cette fausse conscience, et que ne le faisant pas ils ne tombent dans le crime de desobeir à Dieu ; puisqu'ils font une chose qu'ils croient être une desobeissance à Dieu' (OD.II.430).'

${ }^{32}$ CP.II.9 (OD.II.430).

${ }^{33}$ CP.II.9 (OD.II.430-33); and CP.IV.21 (OD.II.520).
} 
this score, suggesting at one point that it doesn't follow that that which is done with conscience is done without crime; at another, that some errors are caused by an 'unforgivable negligence' and therefore culpable, such as the belief in the doctrine of persecution. ${ }^{34}$ But such answers do not sit well with Bayle's otherwise extreme ethics of intention; they invite in new questions and problems, and Mori seems right in suggesting that Bayle's only convincing answer to the paradox necessarily takes him out of his proposed moral framework and into a more pragmatic or political one. ${ }^{35}$ Thus Bayle suggests that, even if persecution is morally innocent,

... all possible Care shou'd be taken to correct it in those who are deceiv'd: for the greater Right it gives to 'em of persecuting, the more fatal it becomes to human Society, and the more fruitful in Calamity and Sin. ${ }^{36}$

But even if Bayle doesn't answer or resolve the question of the conscientious persecutor in a very satisfying way, the example is itself significant, since it is a paradigmatic problem for the budding age of intention; and we will run into the conscientious persecutor again before too long.

Hence, in Bayle, truth (objective truth) slips out of the theory of conscience. What has priority is not whether one knows the truth - since how can anyone know for certain if it is the truth? - but that one believes one knows the truth; that one is truthful or sincere, even when in the wrong. God does not demand of us that we know the truth: 'God demands only that we search for truth sincerely and diligently, and that we discern it by the sentiment of conscience' ${ }^{37}$ To use Lessing's terms, it is God's left hand we are to reach for, and this is the full extent of our duty: there is nothing more that is asked of us beyond the single-minded search for truth. ${ }^{38}$

However, if on the one hand conscience is unburdened of the demands for objective truth, on the other it is re-burdened with the charge of an uncompromising and unremitting purity of intention. This is a revolution moral and conceptual, and while Bayle at this point in history is quite distinctly isolated in his extremity, his ideas signal a wider shift towards subjectivity and interiority, which draws broadly on a deep and growing scepticism about the human ability to access religious truth.

\section{Integrity}

At this point I propose to do something unorthodox and take a leap of almost a century forward, from Bayle to none other than Immanuel Kant; a leap that I think is justified in more ways than one. ${ }^{39}$

${ }^{34}$ CP.II.9 (OD.II.430); and CP.IV.21 (OD.II.520). Rex, Essays, 181, seems to be right in suggesting that Bayle believes the error of persecutor is not invincible. According to Kilcullen ('Bayle', 92), Bayle's 'argument is meant to lead persecutors who may not have been to blame for persecuting to see that persecution is wrong, and they will then deserve blame if they persecute knowing that it is wrong'.

${ }^{35}$ Gianluca Mori, 'Pierre Bayle, the Rights of the Conscience, the "Remedy" of Toleration', Ratio Juris 10, no. 1 (March 1997): $45-$ 60.

${ }^{36}$ CP.IV.21. ' ... quand même cette erreur et ses suites pourraient jouir du privilège des maux que l'on fait involontairement, il ne faudrait pas laisser d'employer tous les soins possibles, pour corriger de cette erreur ceux qui en seraient atteints ; car plus elle leur donnera droit de persécuter, plus deviendra-t-elle funeste à la société publique, et une cause féconde d'une infinité de malheurs, et même de péchés' (OD.II.520).

${ }^{37}$ Quoted in Kilcullen, 'Bayle', 77; see OD.II.441: 'Dieu ne nous demande sinon que nous cherchions sincèrement et diligemment la vérité, et que nous la discernions par le sentiment de la conscience ...'

${ }^{38}$ Lessing's affinity to Bayle on this score is perhaps echoed in the musing of Lessing's former teacher Kästner: 'Lessing fand überhaupt mehr Vergnügen an Untersuchung und Beschäftigung des Verstandes als am ruhigen Besitze der Wahrheit, ohngefähr wie Baile mit dem er soviel Aehnliches hat"; cited in Hugh Barr Nisbet, 'Lessing and Pierre Bayle', in Tradition and Creation: Essays in Honour of Elizabeth Mary Wilkinson, eds C. P. Magill, Brian A. Rowley, and Christopher J. Smith (Leeds: W. S. Maney and Son, 1978), 13-29, at 24. Other than in this article, Bayle's influence on Lessing is briefly discussed by Henry E. Allison, Lessing and the Enlightenment; His Philosophy of Religion and Its Relation to Eighteenth-century Thought (Ann Arbor: University of Michigan , 1966), 16-24, who suggests that Bayle's extension of conscience 'gave birth to the concept of the innocence of error, one of the cardinal beliefs of the Enlightenment' (ibid., 20).

39 It is generally recognised that Kant read Bayle, though the extent of his reading and processing of Bayle's thought remains unclear. For a few cursory discussions see D.A. Rees, 'Kant, Bayle, and Indifferentism', The Philosophical Review 63, no. 4 (October, 1954): 592595; Omri Boehm, Kant's Critique of Spinoza (Oxford: Oxford University Press, 2014), 12; Jean Ferrari, Les sources fran-çaises de la philosophie de Kant (Paris: Librairie Klincksieck, 1979), 91-99; 267-70. On a possible shift in Kant's thoughts on theo-dicy, see Sam Duncan, 'Moral Evil, Freedom and the Goodness of God: Why Kant Abandoned Theodicy', British Journal for the History of Philosophy 20, no. 5 (2012): 973-91. 
In 1791 Kant published an essay on the failure, sometimes horribly mistranslated as 'miscarriage', of any philosophical attempt at theodicy. ${ }^{40}$ It is a remarkable essay for various reasons. For one thing, it is as if written not from beginning to end, but from two directions, from the beginning and from the ending, almost like two separate essays meeting in a curious gap in the middle. This is not to say that the two parts are not related: they are - but they also seem to be doing something quite different.

The first part contains a flat-out exposure of the necessary failure of all philosophical attempts to solve the problem of evil, quite matching Bayle's anti-Augustinian refutation in its sheer philosophical confidence and ambition. Leibniz looms tall in this text, and through Leibniz this topic is inherited almost directly from Bayle: Kant is replying precisely to those philosophers who were replying to Bayle, and rising to Bayle's challenge (his point having been exactly that rational theodicy was doomed to fail). ${ }^{41}$ However, I wish to discuss not this most famous part of Kant's essay, but the intriguing second part, in which the original topic of theo-dicy seems to set off an entirely different train of thought, having to do with truth, conscience, sincerity, integrity, and the Book of Job.

Job might not now seem such an unexpected guest in an essay on theodicy. However, if one looks at the seventeenth-century and early eighteenth-century discussions of the problem of evil, including those by Bayle and Leibniz, it will be noted that Job is remarkably, even conspicuously absent. ${ }^{42}$ Like so many biblical and literary characters, Job dons different roles in different times. Various scholars have remarked upon the 'Job revival' of the eighteenth century: a powerful shift in intensity and scope, spurring new publications, translations, and paraphrases, especially in Germany and England. ${ }^{43}$ One might add to this a shift of orientation: a Job 'reinvention', so to speak. It could tentatively be argued that there is a kind of thematic turn, from repentance to perseverance, in the Enlightenment's interpretations of the Book of Job. Earlier interpretations emphasised the theme of Job as, somewhat paradoxically, both patient and repentant: Job's virtue is proven by his repentance combined with his restoration, which ensures that both God and Job (and perhaps even his friends: for Job did in the end have something to repent at) are ultimately justified. ${ }^{44}$ As opposed to this, the eighteenth century invents a heroic or tragic Job who stays true and stands tall, over and against the hypocrisy of his friends. As Job's restoration sheds its importance, ${ }^{45}$ a change of emphasis occurs: refracted through the myriad pages written on Job are no longer his patience or his repentance so much as his indignation, his integrity, his pious

${ }^{40} / \mathrm{mmanuel}$ Kant, 'Über das Mißlingen aller philosophischen Versuche in der Theodicee' (1791). Despite my reservations about the term 'miscarriage', I have used the translation by George Di Giovanni, 'On the miscarriage of all philosophical trials in theodicy' [hereafter 'Theodicy'], in Kant, Religion and Rational Theology, ed. Allan W. Wood and George Di Giovanni (Cambridge: Cambridge University Press 1996), pp. 19-38. I have added the Prussian academy pagination in brackets after each citation.

${ }^{41}$ On Bayle's discussion of the problem of evil, see e.g. Jean-Pierre Jossua, Pierre Bayle ou l'obsession du mal (Paris, 1977); more recently Michael Hickson, 'Theodicy and Toleration in Bayle's Dictionary', Journal of the History of Philosophy 51, no. 1 (January 2013): 49-73; also his introduction to Pierre Bayle, Dialogues of Maximus and Themistius, ed. Michael W. Hickson (Leiden: Brill, 2016); Van der Lugt, Bayle, esp. ch. 1 and 4.

42See Gianni Paganini's thought-provoking 'Job, Bayle et la Théodicée', in Leibniz et Bayle: Confrontation et dialogue. Studia Leibnitiana 43, eds. Christian Leduc, Paul Rateau, and Jean-Luc Solère (Stuttgart: Franz Steiner, 2015), 363-80. I am, however, less convinced by Paganini's answer to than by his posing of the question. By the time we have reached Pope and Young (not to mention Voltaire), Job and theodicy are all the more entangled; see Jonathan Lamb, The Rhetoric of Suffering: Reading the Book of Job in the Eighteenth Century (Oxford, 1995), 69-81. On debates in biblical criticism regarding Job (e.g. the dating and textual authenticity), see Bertram Eugene Schwarzbach, 'The Eighteenth Century Confronts Job', in History of Universities, ed. Mordechai Feingold (Oxford, 2007), Vol. XXII/1, 141-98.

43Jonathan Sheehan, The Enlightenment Bible: Translation, Scholarship, Culture (Princeton, NJ, and Oxford: Princeton University Press, 2005), 160-76; Sheehan, 'The Poetics and Politics of Theodicy', Prooftexts 27, no. 2 (Spring 2007), 211-32; Lamb, Rhetoric; Susan Neiman, Evil in Modern Thought: An Alternative History of Philosophy (Princeton, NJ/Oxford, 2015), 17-19. A similar development cannot, it seems, be claimed for France; thus Schwarzbach ('Job', 142) remarks upon 'the rather limited appreciation of the book of Job' among French Enlightenment figures.

44For one example: see William Sherlock, A Discourse Concerning the Divine Providence (London, 1715, first publ. 1694), who quells providential objections regarding Job's afflictions by pointing to his rewards and restoration $(131,166)$.

${ }^{45} \mathrm{~A}$ shift perhaps connected to developments in biblical criticism: in 1737 Albert Schultens (Liber Jobi, Leiden 1737) suggested that both prose parts of Job are later additions: not only the Prologue (as had been argued before by Richard Simon in his Histoire Critique of 1685), but also the Epilogue, which includes Job's restoration. The same idea is floated in 1695 by John Toland in a letter sent to unnamed 'Reverend' (A Collection of Several Pieces of John Toland. London, 1726, Vol 2, 315-6). 
perseverance, even in the face of his creator. ${ }^{46}$ It is the 'rhetoric of suffering' (Lamb) or 'poetics of theodicy' (Sheehan) that command the imagination now: the grit and fervour of Job's authentic crying out to God. It is this development that is echoed so strikingly in this essay by Kant.

\subsection{Job and sincerity}

There's a point in Kant's essay where everything seems to come to a halt. Kant has already developed his case for the failure of all rational theodicy, he has made his argument, he has proven his point: he could just have ended there. Instead, after having demonstrated the failure of theodicy, Kant introduces a distinction between two kinds of theodicy, one doctrinal and one authentic (where the term authentic relates to originality, similar to an authentic legal document as opposed to a mere copy). ${ }^{47}$ Doctrinal theodicy is when we see the world as a publication of God's purposes and we try to infer God's will from his work. Authentic theodicy is when God 'becomes himself the interpreter of his will' through our reason, by which we form our concept of God as a moral and wise being. ${ }^{48}$ This is the kind of theodicy that Kant reads in the Book of Job.

Job, besieged by God, is pressured by his friends to declare his guilt and to confess that he must have a bad conscience: after all, had he truly been innocent, why would God strike him down? Kant draws our attention to the 'spiriy', the character [Character] of the two sides of the debate:

Job speaks as he thinks, and with the courage with which he, as well as every human being in his position, can well afford; his friends, on the contrary, speak as if they were being secretly listened to by the mighty one, over whose cause they are passing judgment, and as if gaining his favour through their judgment were closer to their heart than the truth. ${ }^{49}$

The opposing characters, therefore, are, on the one hand, the spirit of frankness and honesty (bordering on 'impudence'), associated with Job; and on the other, the spirit of flattery and hypocrisy, associated with the friends. Kant continues:

If we now consider the theoretical position maintained by each side, that of Job's friends might convey more of an appearance of greater speculative reason and pious humility; before any court of dogmatic theologians, before a synod, an inquisition, a venerable congregation, or any higher consistory in our times (one alone excepted), Job would have likely suffered a sad fate. ${ }^{50}$

And yet, in the end, God finds against Job's friends, for in terms of conscientiousness [Gewissenhaftigkeit], Job's friends have not spoken as well of God as Job has. From this we can conclude that:

... only sincerity of heart [Aufrichtigkeit des Herzens] and not distinction of insight; honesty [Redlichkeit] in openly admitting one's doubts; repugnance to pretending conviction where one feels none, especially before God (where this trick is pointless enough) - these are the attributes which, in the person of Job, have decided the preeminence of the honest man [des redlichen Mannes] over the religious flatterer in the divine verdict. ${ }^{51}$

Hence, Job is represented as full of doubts, but as fully sincere of heart, since he refuses to 'pretend conviction where he feels none', and since he openly admits his doubts. He may well be wrong, and

${ }^{46}$ See Lamb, Rhetoric, 117-8. See also Neiman (Evil, 17), who overstates the point somewhat: 'Sometime during the Enlightenment, commentators stopped looking for ways in which Job's torments could be justified. [...] Earlier writers identified with Job's friends, the theodicy-makers who found justification. Later ones identified with Job, who found none.'

${ }^{47}$ See Susan Meld Shell, 'Kant's Secular Religion: Philosophical Theodicy and The Book of Job', in Rethinking Kant: Volume 3, ed. Oliver Thorndike (Newcastle upon Tyne: Cambridge Scholars, 2011), 20-32, at p. 26;

${ }^{48}$ Kant, 'Theodicy', 31 (8: 264).

${ }^{49}$ Kant, 'Theodicy', 32 (8:265).

50Kant, 'Theodicy', 33 (8:266). Kant's 'one alone excepted' refers to the Berlin High Consistory; see Di Giovanni, 'Translator's Introduction', in Kant, 'Theodicy', 21.

${ }^{51}$ Kant, 'Theodicy', 33 (8:266-7); see Lamb, Rhetoric, 65. See also Kant's letter to J.C. Lavater (28 April 1775), where Kant styles himself ' $[\mathrm{a}]$ man who believes that, in the final moment, only the purest candor concerning our most hidden inner convictions can stand the test and who, like Job, takes it to be sin to flatter God and make inner confessions, perhaps forced out by fear, that fail to agree with what we freely think'. Kant, Philosophical Correspondence 1759-99, trans. Arnulf Zweig (Chicago: University of Chicago Press, 1967), 79-80. 
his friends, who hold the more convincing theoretical position, may be right, but God prefers Job for the purity of his intentions, his resistance to hypocrisy.

The crucial verse, for Kant, is Job 27:5, where Job in the midst of his strongest doubts, could yet say': 'Till I die I will not remove mine integrity from me'. ${ }^{52}$ The crucial virtues, in matters of faith, are those of sincerity and honesty (Aufrichtigkeit and Redlichkeit): 'sincerity in taking notice of the impotence of our reason', and 'honesty in not distorting our thoughts in what we say, however pious our intention'. ${ }^{53}$ It is better to doubt sincerely than to express a truth half-heartedly.

\subsection{Oaths, lies, and conscientious inquisitors}

Finally, Kant adds a 'Concluding Remark' to the essay, which he wrote in response to a recent controversy on religious oaths. Recall how the intensification of oath-taking was exactly part of the development towards inwardness that took off in the seventeenth century; a response to the perceived threat of the radical 'mental privacy' installed in the modern conscience. ${ }^{54}$ The same issue comes up again in Kant's time, when the new regime of Frederick William II required theology students to profess their faith by means of a formal oath, a form of 'spiritual torture' to which Kant was deeply opposed. ${ }^{55}$ This theme he weaves into his essay on theodicy, which has become an essay on sincerity (and on Job as its fountainhead), and now manifests an abrupt irruption of the historical background into the philosophical foreground, as Kant enters into:

... [a] brief reflection on a big subject, namely sincerity [Aufrichtigkeit], which is the principal requirement in matters of faith, as contrasted with the propensity to falsehood and impurity [Falschheit und Unlauterkeit] which is the principal affliction of human nature..$^{56}$

He begins by contrasting truth, associated with the understanding, and truthfulness, associated with conscience:

One cannot always stand by the truth [das wahr sei] of what one says to oneself or to another (for one can be mistaken); however, one can and must stand by the truthfulness [das wahrhaft sei] of one's declaration or confession, because one has immediate consciousness of this. ${ }^{57}$

If we make a declaration without bringing it before our conscience and being conscious that it is truly what we believe, 'then we lie [so lügt er], since we pretend something else than what we are conscious of'. ${ }^{58}$ This truthfulness Kant calls formal conscientiousness [formale Gewissenhaftigkeit], which consists in the care in becoming conscious of this belief (or unbelief) and not pretending to hold anything as true we are not conscious of holding as true'. ${ }^{59}$

52Job 27:5 KJV. In Kant's version: 'Bis dass mein Ende kommt, will ich nicht weichen von meiner Frömmigkeit.' Frömmigkeit (which goes back to Luther's Frömkeit) is more akin to piety than 'integrity'. The original Hebrew term is tumma, innocence or integrity. French translations also include intégrité (Martin 1707) and innocence (Calvin 1551); the Septuagint has ákakía, guilelessness or innocence. Note that in the early modern period 'integrity', which originally meant 'wholeness' or 'intactness', seems to grow increasingly into its now common moral meaning of uprightness and probity.

53Kant, 'Theodicy', 34 (8:267).

${ }^{54}$ Bracken, 'Minds and Oaths', 68; see above, 'Error'.

${ }^{55}$ This is my interpretation. Kant offers a lengthy footnote in which he seems to be justifying certain kinds of oaths, such as the 1790 theological oath recently instated by J.C. Wöllner, while 'implying that it had no theoretical content' (Di Giovanni, 'Translator's Introduction', in Kant, 'Theodicy', 22); it might hence be taken as 'damage control' (ibid.). Taking into account the stark contrast between the firm, ardent tone of the main text and the tepidity of Kant's convoluted footnote, I see the latter as precautionary. On the historical background, see Allen W. Wood, 'General introduction', in Kant, Religion, xv-xxii; Shell, Kant and the Limits of Autonomy (Cambridge, MA/London: Harvard University Press, 2009), 187-8.

${ }^{56}$ Kant, 'Theodicy', 34 (8:267). According to Shell, 'Kant's Secular Religion', 29, this is the first time Kant 'explicitly identifies falsehood [...] as the main weakness of human nature, a position he will hereafter consistently maintain.' Similar in Kant, 189-90: 'Henceforth, Kant will stress inward sincerity [...] as the sine qua non of all effective efforts at moral self-improvement.' See also Duncan, 'Moral Evil', 989 : 'from this point on self-deception is the only thing that Kant will appeal to in explaining immorality.'

57Kant, 'Theodicy', 34 (8:267).

58Kant, 'Theodicy', 34 (8:267).

${ }^{59}$ Kant, 'Theodicy', 34 (8:268). Material conscientiousness 'consists in the caution of not venturing anything on the danger that it might be wrong' (ibid.). 
if someone says to himself (or - what is one and the same in religious professions - before God) that he believes, without perhaps casting even a single glimpse into himself - whether he is in fact conscious of thus holding a truth or at least of holding it to some degree -then such a person lies. ${ }^{60}$

And this, according to Kant is not just any lie, but the most absurd and sinful lie of all (die ungereimteste... [und] frevelhafteste [Lüge] $)^{61}$

Now it is well known that Kant was categorically against lying, even with good intentions, as he was to make clear a few years later in his famous essay 'On A Supposed Right to Lie From Altruistic Motives' ${ }^{62}$ And in fact the second part of the essay on theodicy can be seen as a counterpart of the essay on lying, but there are two important differences at play. First, while the concern of the essay on lying is with external deception, the concern in the essay on theodicy is with internal deception or selfdeception:

Iam here restricting myself principally to the impurity [Unlauterkeit] that lies deep in what is hidden, where the human being knows how to distort even inner declarations before his own conscience [Gewissen]. ${ }^{63}$

This concern with self-deception - a theme that, like truthfulness, rose to the fore in the wake of the seventeenth-century Augustinian surge ${ }^{64}$ - also informs Kant's theory of conscience, the concept of which he reinvents entirely. ${ }^{65}$

Conscience, in Kant, is not the faculty of moral judgment itself. Rather it is a higher-order tribunal $^{66}$ that inquires whether or not the case in question, all the arguments for and against, have been duly examined. It is, ultimately, a faculty that is to prevent moral (and perhaps religious) laxity; it could be defined as 'the moral faculty of judgment, passing judgment upon itself'. As Kant explains:

here reason judges itself, whether it has actually undertaken, with all diligence, that examination of actions (whether they are right or wrong), and it calls upon the human being himself to witness for or against himself whether this has taken place or not. ${ }^{67}$

In his Religion Within the Boundaries of Mere Reason Kant tests this theory against something we might almost expect by now - but after all nobody expects the conscientious inquisition. ${ }^{68}$ According to Kant, it is indeed possible that a hypothetical inquisitor [Ketzerrichter] is acting out of a sincere belief in duty; that he firmly believes that God permitted or even obliged him to persecute, based on some kind of revelation, such as Christ's saying 'compellite intrare'. ${ }^{69}$ But what we should ask ourselves is this: did this inquisitor have enough certainty of such a revealed doctrine and its meaning 'as is required for daring to destroy a human life on its basis?' After all, according to Kant, we can never be completely certain of the authenticity of any revelation, especially when it is mediated through human beings, but even when it appears to come from God himself: it's always possible that error has occurred. (As an example Kant mentions 'the command issued to Abraham to slaughter his

${ }^{60}$ Kant, 'Theodicy', 34-5 (8:268).

${ }^{61}$ Kant, 'Theodicy', 35 (8:268-9). See below, n. 74, on a similar opinion in Arendt.

${ }^{62 K a n t, ~ ' U ̈ b e r ~ e i n ~ v e r m e i n t e s ~ R e c h t ~ a u s ~ M e n s c h e n l i e b e ~ z u ~ l u ̈ g e n ' ~(1797) . ~}$

63Kant, 'Theodicy', 36 (8:270). Compare also this much earlier passage from one of Kant's lectures, written down by J. G. Herder (1762-): 'Nowadays, however, there is untruth, not merely in the world, but also before God, in solitude, since we cannot stand even before Him without pretence. To be truthful, we would now have to forfeit a great deal, and so each of us shies away from the truth, and most of all in a nightshirt. Untruth may end by deceiving itself, and so self-examination becomes equally slippery; [...] and men eventually become deceivers even towards God: for example, Job's comforters. [...] The importance of the love of truth is so great that one can almost never make an exception to it.' Kant, Lectures on Ethics, trans. P. Heath, ed. P. Heath and J.B. Schneewind (Cambridge: CUP, 2001), 27 (27:61).

${ }^{64}$ See above, 'Error'.

${ }^{65}$ For some recent discussions of Kant on conscience, see Emre Kazim, Kant on Conscience: A Unified Approach to Moral Self-Consciousness (Leiden/Boston: Brill, 2017); Martin Sticker, 'When the Reflective Watch-Dog Barks - Conscience and Self-Deception in Kant', The Journal of Value Inquiry 51, no. 1 (2017): 85-104; Jens Timmermann, 'Kant on Conscience, "Indirect" Duty and Moral Error', International Philosophical Quarterly 46, no. 9 (2006): 293-308.

${ }^{66}$ Here I follow Kazim, Kant, though leaving open the question whether conscience is a second-or third-order faculty.

${ }^{67 K a n t}$, Religion Within the Boundaries of Mere Reason, in Religion and Rational Theology, 55-215, at 203 (6: 186).

${ }^{68}$ See above, 'Error' on Bayle and the conscientious persecutor. Kazim (Kant, 103) suggests that Kant, in discussing the inquisitor and the erring conscience, is responding to Bayle.

${ }^{69 K a n t, ~ R e l i g i o n, ~ 203-4 ~(6: ~ 187) . ~ O n ~ K a n t ' s ~ i n q u i s i t o r, ~ s e e ~ K a z i m, ~ K a n t, ~ 102-7 ; ~ T i m m e r m a n n, ~ ' K a n t ', ~ 305-6 . ~}$ 
own son like a sheep'. $)^{70}$ This means that, if the inquisitor were to act on such a less-than-certain belief, he 'would risk the danger of doing something which would be to the highest degree wrong, and on this score he acts unconscientiously'. Similarly, if any spiritual authority would impose certain articles of faith or external expressions of faith on people, this authority 'would himself be acting against his conscience, by forcing upon others a belief in something of which he cannot himself be ever wholly convinced'. The forcing of conscience can thus never be justified by conscience itself. ${ }^{71}$ Hence, though it can perhaps be said that an inquisitor or persecutor has acted in good faith, it cannot be said he acted out of conscience. His main error is that he has not acquired the level of certainty that is required to justify putting someone to death; he has not examined the case with sufficient rigour. Therefore, he has not acted conscientiously, and this constitutes the core of his failure as a moral agent and a human being. ${ }^{72}$

This failure ties into the second difference between the essay on lying and that on theodicy: for while the essay on lying focuses mainly on one's duty towards others, the essay on theodicy (at least the second half) prioritises one's duty towards oneself: 'to refrain from deception rests on the character [Charakter] which the human being himself must build within himself'. ${ }^{73}$ Kant associates the kind of 'mendacity' or 'falsity' [Lügenhaftigkeit, Falschheit] that is the topic of this essay with baseness, 'whereby all character is denied to the human being': 'Nichtswürdigkeit, wodurch dem Menschen aller Charakter abgesprochen wird'. ${ }^{74}$ Something worthy of contempt [verachtungswürdig]. ${ }^{75}$

Kant's plea for sincerity is thus coupled with a deep concern for character or integrity: the uncorruptedness, unbrokenness of the self; a certain care for one's own humanity, one's inner human core. Oaths are so detrimental, to the individual as well as to society as a whole, ${ }^{76}$ precisely because they encourage inner lies and discourage the kind of inward gaze that Kant associates with conscience. They endanger the building up of this character, this integrity, that is so crucial for being and becoming that rare thing: a truly sincere, authentic human being. This is why Job becomes a hero of conscience and integrity, for Kant. For Job has cast his gaze deeply into himself and refuses to say anything other than what he consciously and conscientiously believes.

Kant thus seems to suggest, like Bayle, that it is infinitely better, and more moral, and more appealing to God, to declare oneself for one's beliefs, even if these are objectively false, so long as one wholeheartedly believes them. In both thinkers, on either side of the eighteenth century, morality and faith entail a crucial prioritisation of subjective truthfulness over objective truth. The faithful heretic, in Bayle, is justified through the wholeheartedness of his conviction; the faithful doubter (Job) in Kant is justified through the purity of his intention combined with the rigour of his self-examination. The lie now resides not primarily in its opposition to truth, but in its opposition to sincerity.

Note the demands that are now placed on conscience: the demands of utter inwardness. What is now crucial is not the examination: 'what is truth?', but the self-examination: 'what do $I$

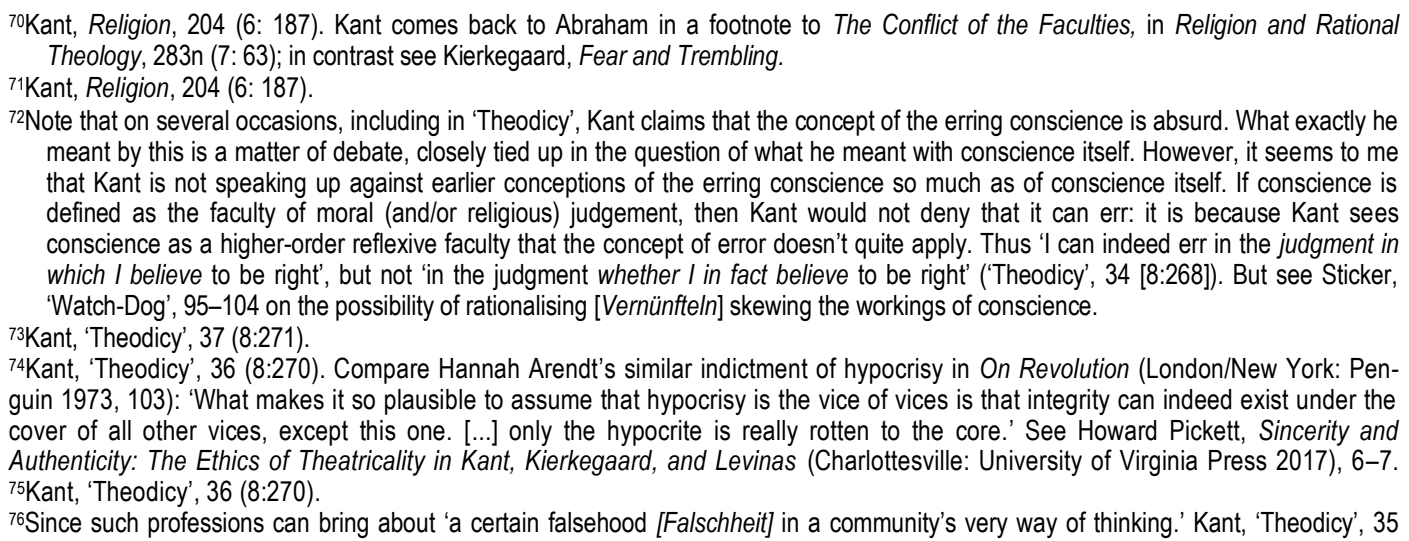
(8:269). 
believe?' - and this is the meaning of conscience and conscientiousness. Self-reflective inwardness has become a duty but also a problem: how to turn this gaze truly inward, how to avoid lying to oneself? Much more than Bayle, Kant is concerned with self-deception, and with the propensity of oaths distorting not only one's external expressions, but one's very declarations to oneself. In this emphasis on the duty towards oneself, this language of privacy and utter interiority, of sincerity and integrity, Kant is moving ever closer to that very modern concept: authenticity. ${ }^{77}$

\section{Authenticity}

This is an item that should be handled with some caution. The modern term has a muddled history: originating in Heidegger's Eigentlichkeit, which was translated by Sartre as authenticité, it was then read back into earlier thinkers like Kierkegaard, whose Danish Alvor actually means something more like earnestness. ${ }^{78}$ Whatever the preambles, authenticity has become an incredibly important part of our moral landscape, to such an extent that Charles Taylor has proposed: 'Let's call this the Age of Authenticity' ${ }^{79}$

Often authenticity is considered more or less equivalent with sincerity, since both are modes of 'self-congruence'. ${ }^{80}$ But authors such as Lionel Trilling and Bernard Williams make a subtle yet important distinction between the two, which is historical as well as conceptual. ${ }^{81}$ Sincerity is considered the earlier concept, and an intrinsically social one; the recurrent quote to illustrate this is drawn from Shakespeare: 'to thine own self be true, and it must follow, as the night the day, thou canst not then be false to any man'. This is taken to mean that one must be true to oneself in order not to be false to others. ${ }^{82}$ Sincerity is thus strongly associated to virtue and (social) duty; Trilling relates it to Hegel's concept of the bourgeois 'honest soul'. Authenticity, on the other hand, is a somewhat later concept that has more to do with being true to oneself for its own sake, regardless of one's duties or commitments to others. It can thus be opposed to virtue and even to sincerity. One can be authentic and not sincere, or sincere and not authentic, such as Williams sees in the case of Rousseau's Julie. ${ }^{83}$ Associated strongly with the heroic, authenticity suggests, in Trilling's words, 'a more strenuous moral experience' than sincerity does; he relates it to Hegel's concept of a 'disintegrated consciousness'. ${ }^{84}$

Trilling (and others in his footsteps) thus describes a historical development of our moral background: 'at a certain point in its history the moral life of Europe added to itself a new element, the state or quality of the self which we call sincerity' ${ }^{85}$ This is coupled with a subsequent transition to authenticity, and both are connected to an increasing movement towards inwardness, subjectivity, and individuality. ${ }^{86}$

\footnotetext{
${ }^{77}$ Kant is usually associated with autonomy rather than authenticity; but I think the latter term can be productively applied to Kant's essay on theodicy. On this distinction see Somogy Varga, Authenticity as an Ethical Ideal (New York: Routledge, 2011), 2-5, 17-20; Alessandro Ferrara, Reflective Authenticity: Rethinking the Project of Modernity (London: Routledge, 1998), 5-10.

78See Pickett, Rethinking, 163-4.

${ }^{79}$ Charles Taylor, A Secular Age (Cambridge, MA and London: Harvard University Press, 2007), 473.

${ }^{80}$ See Pickett, Rethinking, 8.

${ }^{81}$ Lionel Trilling, Sincerity and Authenticity (Cambridge, MA: Harvard University Press, 1972); Bernard Williams, Truth and Truthfulness: An Essay in Genealogy, (Princeton, NJ: Princeton University Press, 2002), ch. 8 ('From Sincerity to Authenticity').

82Trilling, Sincerity, 3-6 (quoting William Shakespeare, The Tragedy of Hamlet, Prince of Denmark, Act 1, Scene III); this is taken up by, e.g. Varga, Authenticity, 15; Pickett, Rethinking, 8; and by the Stanford Encyclopedia of Philosophy: article 'Authenticity' by Somogy Varga and Charles Guignon, (Fall 2017 Edition), ed. Edward N. Zalta, https://plato.stanford.edu/archives/fall2017/entries/ authenticity/ (accessed January 23, 2018). However, some authors on authenticity, such as Charles Taylor and Charles Guignon, have stressed its intrinsically social dimensions; see Varga, Authenticity, 28-30.

83Williams, Truth, 183; see also Varga, Authenticity, 16.

84In the Phänomenologie des Geistes, Hegel relates the 'honest soul' to the Moi of Diderot's Neveu de Rameau, and the opposing 'disintegrated consciousness' to the Lui; Trilling in turn associates these to sincerity and authenticity, respectively (Sincerity, 2752); Williams unpacks this further (Truth, 185ff).

85Trilling, Sincerity, 2.

${ }^{86}$ See Charles Taylor's classic Sources of the Self: The Making of the Modern Identity (Cambridge, MA: Harvard University Press, 1989); also his Secular Age and The Ethics of Authenticity (Cambridge, MA: Harvard University Press, 1991).
} 
Thus we go from something undefined to sincerity to authenticity. But it is unclear what the character is of the first part of this shift. What precedes this ethic of sincerity, what drives this change? What is it exactly that gets left behind? The answer, or part of the answer, goes back to what Hannah Arendt said gets lost in the Enlightenment, what Lessing said gets left in God's right hand. And this brings me back, at long last, to the topic of this essay, the reason why for speaking of error and integrity at all. Truth and lie: these are terms that have a history, and a history that lies not primarily in the concepts of truth and lie on their own, but in the very nature of their opposition to each other. It seems that a shift can be traced in the core oppositions that make up the moral background of different thinkers at different times. With the risk of oversimplification, but the benefit of clarity, this shift can be summarised as follows. ${ }^{87}$ First, for most of Western history, the fundamental opposition is between truth and all that is opposed to it: a conglomerate of falsehood, lies, and error. What is primary is not the intention behind the falsehood (which would distinguish lie from error), but its character as (objectively) false, as being opposed to truth. Second, in what, with some exaggeration, might be called the Age of Sincerity, this opposition is picked apart and divided into two new oppositions:

(i) Truth as opposed to falsehood and error.

(ii) Truthfulness or sincerity as opposed to lies and hypocrisy.

This is coupled, furthermore, with a shift of prioritisation: the second opposition gradually comes to take precedence over the first. In ever stronger foreshadowings of Kierkegaard, subjective truth begins to take over from objective truth.

This is the development in which various of these threads of thought are tied together: such as conscience and the things that threaten it (oaths, violence, compelle intrare), but also Job as the newfound hero of integrity. I have featured Bayle and Kant precisely because it seems that Bayle stands at the beginning of a development that is completed in Kant and Lessing, who prioritise morality over religion just as they prioritise sincerity over objective religious truth. ${ }^{88}$ If we go back to Lessing for a moment, the passage of the left hand calls to mind the even more famous parable of the three rings from his play Nathan the Wise - a play that itself reverberates with Job. ${ }^{89}$ The father in the story recounted by Nathan to Saladin makes two copies of the coveted ring so he can give one to each of his three sons, but he doesn't tell them which is the real one - the objectively true one. Arendt also brings this parable to mind and suggests:

The German Enlightenment as represented by Lessing did not simply lose truth as religious revelation, but rather the loss is seen as something positive: the discovery of the purely human. ${ }^{90}$

And this is what is held in the left hand of the Enlightenment. It is not simply the single-minded striving after truth, but rather a cluster of concepts and associations: humanity, individuality, integrity, sincerity, set over and above what almost seems to be a trifle, a residue: that crazy little thing called truth.

\footnotetext{
${ }^{87}$ Note that I'm speaking of moral and religious belief (which I'm taking as including disbelief) rather than scientific truth. Note also that history does not deal in pictures and schemata so neat as that sketched here, and I should like to stress its fragility and openendedness. The back-and-forthing of this particular history can be illustrated by figures such as Blaise Pascal and Samuel Johnson, who stressed the importance of liturgical formalism as opposed to an ethic and faith of Baylean-Kantian sincerity; I thank Conrad Brunstrom for pointing this out.

${ }^{88}$ The key sentence in Kant's 'Theodicy' is perhaps the one following the key verse (Job 27:5) in which Kant suggests that 'with this disposition [Job] proved that he did not found his morality on faith, but his faith on morality', which is a perfect summary of Kant's view of the relationship between morality and religion. I thank Ritchie Robertson and Anthony La Vopa for pointing this out to me.

${ }^{89}$ See Ingrid Strohschneider-Kohrs, Vernunft als Weisheit: Studien zum späten Lessing (Tübingen: Max Niemeyer, 1991), 62-90, on Job connotations in scene IV.7 of Nathan der Weise.

${ }^{90}$ Arendt, 'The Enlightenment', 4.
} 
Finally, in Taylor's 'Age of Authenticity', a third opposition is added, again moving up in the order of precedence:

(iii) authenticity as opposed to inauthenticity.

Now I am not so certain that the distinction between sincerity and authenticity always works. If we take it strictly, then Bayle's faithful heretic and Kant's Job should perhaps be described in the category of the authentic rather than sincere, since their integrity is not defined in terms of social duty but of pure individual consciousness, pure sense of self. Trilling may be right that we do not find the heroic in the Bible; that 'Oedipus confronting the mystery of human suffering is a hero; Job in the same confrontation is not' ${ }^{91}$ But Job becomes a hero in the eighteenth century precisely because he is reinvented as one who confronts his suffering and perseveres in full integrity, sincerity, and (I would say) authenticity. ${ }^{92}$ Suffering can become heroic because it is coupled with radical integrity.

For understanding the history of each of these concepts, it is crucial to see how they are rooted in the most conflicted questions and crises of conscience. It is precisely because the new conceptual space of conscience was seen and experienced as under attack that notions of inwardness were able to develop so strongly and so quickly throughout the long eighteenth century.

This is an item often neglected by those who criticise the modern ethic of authenticity for energising selfishness and narcissism rather than virtue, morality, and other-directedness. ${ }^{93}$ It is not that such criticisms cannot be made (they can and should), but that they risk a certain complacency: it is easy to criticise the ethics of sincerity or authenticity when the background conditions of this very sincerity, such as freedom of conscience, are already in place. But it ought to be remembered that this ethic of sincerity was inextricably tied up with a prolonged attempt to defend that fragile thing, the modern conscience, from external pressures, such as religious persecution (in Bayle) and religious oaths (in Kant).

With Kant we have reached the closing years of the eighteenth century, and I will end by stepping just briefly into the nineteenth, where singleness and inwardness and the 'sentiment of being' would make their great conquests in the history of ideas. ${ }^{94}$ It is at this time that William Wordsworth, who like Rousseau, like Kant perhaps, stands on the very fault line between sincerity and authenticity, can make his profoundly Joban exclamation:

Points have we all of us within our souls

Where all stand single. ${ }^{95}$

\section{Disclosure statement}

No potential conflict of interest was reported by the author.

\footnotetext{
91Trilling, Sincerity, 86.

${ }^{92}$ As an example of authenticity as opposed to sincerity, Trilling (Sincerity, 93-4) mentions Wordsworth's grieving Michael, from the poem of the same name. While Michael and Job are in stark contrast in one way (the latter expressing his grief while the former 'expresses nothing [...] he and his grief are one'), I think the concept of authenticity can certainly be applied to the modern Job, who, like Michael in Trilling's description, 'is as actual, as hard, dense, weighty, perdurable as any stone he lifts up or lets lie.'. ${ }^{93}$ For a helpful précis of the 'critics of authenticity', such as Christopher Lasch and Allan Bloom, see Varga, Authenticity, 25-28. ${ }^{94}$ See Trilling, Sincerity, esp. 92, on the 'sentiment of being' in Rousseau and Wordsworth.

${ }^{95}$ William Wordsworth, The Prelude: 1799, 1805, 1850, ed. Jonathan Wordsworth, M.H. Abrams and Stephen Gill (New York: Norton Critical Editions, 1979), book III, v. 186-7; these lines first published in the 1805 edition. See also Trilling, Sincerity, 103; Laurent Folliot, 'Points have We All of Us Where All Stand Single": Wordsworth's Impersonal Autobiography', Etudes anglaises 66, no. 4 (2013): 441-56.
} 